Available online at GSC Online Press Directory

GSC Biological and Pharmaceutical Sciences

e-ISSN: 2581-3250, CODEN (USA): GBPSC2

Journal homepage: https://www.gsconlinepress.com/journals/gscbps

(RESEARCH ARTICLE)

\title{
CHRNA5/CHRNA3 polymorphisms and tobacco smoking risk in a Brazilian population sample
}

\author{
Caroline de Lima Mota ${ }^{1,}{ }^{*}$, Simone Mitri ${ }^{1}$, Cristiane Barata-Silva ${ }^{2}$ and Josino Costa Moreira ${ }^{1}$ \\ ${ }^{1}$ Department of Toxicogenetics, Center for Studies of Worker's Health and Human Ecology, Oswaldo Cruz Foundation, Rio \\ de Janeiro, Brazil. \\ ${ }^{2}$ Department of Chemistry, Inorganic Contaminants Section, Oswaldo Cruz Foundation, Rio de Janeiro, Brazil.
}

Publication history: Received on 04 August 2020; revised on 13 August 2020; accepted on 15 August 2020

Article DOI: https://doi.org/10.30574/gscbps.2020.12.2.0253

\begin{abstract}
Tobacco smoking is a major risk factor of several diseases such as lung cancer, stroke, chronic obstructive pulmonary disease and increases the susceptibility to infectious diseases. The understanding of smoking addiction requires phenotyping and genotyping studies. Variations in CHRNA5/CHRNA3 can alter receptor responses to nicotine and thus interfere with smoking behavior and risk. Therefore, this study aimed to investigate the association of $C H R N A 5$ rs16969968 and CHRNA3 rs578776 with smoking behavior in a Brazilian population sample, comprising 449 subjects. Smoking data was obtained from a questionnaire. The polymorphisms were genotyped by Polymerase Chain Reaction (PCR). Associations were verified using logistic and linear regression analyses. We found that women with the variant $A A$ genotype for CHRNA5 rs16969968 were at significantly increased risk of smoking, with an 0R of 3.09 (95\% CI: 1.09 8.76; $\mathrm{p}=0.033$ ). The variant TT genotype of CHRNA3 rs578776 showed protection against smoking and later smoking initiation in the overall population and in women, with an OR of 0.41 (95\% CI: 0.19-0.88; p=0.022). In conclusion, CHRNA5 rs16969968 and CHRNA3 rs578776 were associated with increased risk and protective effect against smoking, respectively, in a Brazilian population sample. Gender and recessive homozygosis of the polymorphisms variants resulted in a significant effect regarding the results.
\end{abstract}

Keywords: Tobacco smoking; Public health; Nicotinic receptors; Genetic polymorphism; CHRNA polymorphisms; Smoking behavior.

\section{Introduction}

Smoking is a worldwide problem Public Health responsible for over 8 million deaths a year. Tobacco use is the leading cause of preventable death and has been associated with an increased risk for several diseases, including cardiovascular diseases, lung disorders, stroke, and several types of cancer [1, 2].

Cigarettes are the main source of tobacco consumption, containing over 7000 different chemical substances [2]. Nicotine is the major tobacco substance that establishes and maintains cigarette smoking dependence [3]. Like other psychostimulants, nicotine modulates dopamine activity in the midbrain, specifically the mesocorticolimbic system, which is involved in feeling pleasure when smoking $[3,4]$.

Nicotine is an acetylcholine agonist that binds to nicotinic acetylcholine receptors (nAChRs). These receptors are formed by subunits and are distributed in the central and peripheral nervous system, as well as other tissues such as muscle and the endothelium. The arrangement between subunits results in receptors differentially distributed throughout the

\footnotetext{
${ }^{*}$ Corresponding author: Mota Caroline de Lima

Department of Toxicogenetics, Center for Studies of Worker's Health and Human Ecology, Oswaldo Cruz Foundation, Rio de Janeiro, Brazil
} 
body and presenting differential pharmacological properties and responses to nicotine stimulation. Repeated exposure to nicotine can decrease nAchRs responses, leading to their desensitization [5,6]. Consequently, increased nicotine consumption is required to maintain the same response linked to dopamine effects [4]. Some of these receptors are codified by the CHRNA5-CHRNA3-CHRNB4 gene cluster on chromosome 15q25.1, which contains single nucleotide polymorphisms (SNPs) associated with nicotinic dependence [7,8]. These SNPs include $C H R N A 5$ rs16969968 $G>A$, and CHRNA3 rs578776 $C>T$, both associated with smoking behavior characteristics, such as number of cigarettes a day (CPD) $[9,10,11]$, age of smoking initiation [12,13], dependence degree as defined by the Fagerström Test for Nicotine Dependence (FTND) [13,14], number of quitting attempts [15,16], smoking cessation [17,18] and heavy smoking $[19,20]$.

Variants in these genes that encode proteins related to nicotine addiction in some mestizo population are associated with cigarette smoking and prevalence of tobacco-related diseases [21]. Apparently, this is the case of Brazil, a country characterized by having a mixed population. However, very few studies have been carried out in the Brazilian population [22,23].

According to Vigitel Brasil 2019, in Brazil, the frequency of adult smokers was 9.8\%, being higher in males (12.3\%) than in females (7.7\%) and a frequency of passive smokers at home was 6.8\%, being similar between men and women [24]. Although smoking prevalence has decreased in Brazil due to the actions of the National Tobacco Control Policy, tobacco use is still responsible for 156.216 deaths per year, representing high social and economic costs for the country [24,25]. $74 \%$ of deaths caused by chronic obstructive pulmonary disease (COPD), $16 \%$ of deaths from heart diseases, $13 \%$ from stroke, and $78 \%$ from lung cancer are due to the consumption of tobacco. Annual costs with smoking reach up to R\$ 56.9 billion in Brazil, of which $\mathrm{R} \$ 39.394 .369 .233$ are spent directly on the treatment of related diseases, and $\mathrm{R} \$$ 17.503.786.333 with consequent associated loss of productivity [25]. In this context, this study aimed to investigate potential associations between the $C H R N A 5$ rs16969968 $G>A$ and $C H R N A 3$ rs578776 $C>T$ variants, smoking status risk, and smoking behavior characteristics in a Brazilian population sample.

\section{Material and methods}

\subsection{Study design and population}

A total of 449 subjects from Duque de Caxias city in Rio de Janeiro, Brazil, were enrolled in a cross-sectional study with between 2016 and 2019 by a convenience sampling. The study was open to participation by both male and female individuals over 18 years old. The study was approved by the Oswaldo Cruz Foundation Sergio Arouca National School of Public Health (ENSP) ethical committee, number CAAE 40514415.0.0000.5240. Informed consent was obtained from all individual participants included in the study. The participants were interviewed by trained personnel, and a questionnaire was applied to obtain general information, including demographic characteristics.

\subsection{Smoking status}

Smoking status was defined based on available self-report questionnaire data. According to the smoking status, study participants were classified into never, current and former smokers. Current smokers had smoked at least 100 cigarettes during their lifetime, never smokers had smoked less than 100 cigarettes or had never smoked regularly, and former smokers had quit smoking for $\geq 1$ year at the time of interview. The FTND was used to assess the nicotine dependence degree in Current smokers [26]. The risk of smoking was evaluated between Never smokers and Ever smokers (Current and Former smokers). Age of initiation and CPD were also evaluated as smoking behavior among Ever smokers.

\subsection{Genotyping}

Approximately $5 \mathrm{~mL}$ of blood samples were collected from each study participant, and stored under refrigeration until DNA extraction, carried out by the salting-out method from whole blood. After extraction, the genomic DNA amount was assessed at $260 \mathrm{~nm}$ and DNA quality was evaluated through the 260/280 nm ratio using a NanoDrop 2000 spectrophotometer (Thermo Fisher ScientificTM). SNPs were determined using TaqMan single nucleotide polymorphism Genotyping Assays (assay IDs: rs16969968: C_26000428_20; rs578776: C_721253_10), whose amplifications were conducted according to the manufacturer's instructions and performed on a 7500 real-time PCR (Polymerase Chain Reaction) platform (Applied Biosystems). In order to verify genotyping efficiency, random samples were selected and re-genotyped for each SNP (10\% of all samples). 


\subsection{Statistical analysis}

Statistical analysis was carried out using the SPSS statistical software package 20.0 (Statistical Package for Social Sciences Inc., Chicago, IL, USA). Data normality distribution was assessed by the Kolmogorov-Smirnov test. Continuous variables were presented as means and standard deviation (SD), while categorical data were expressed as frequencies. The Mann-Whitney U-test and $\chi 2$-test were used to evaluated differences between means and frequencies.

Possible associations between CHRNA3 rs578776 and CHRNA5 rs16969968 SNPs with risk of smoking was assessed by applying a logistic regression, considering smoking status as the dependent variable and age, gender, skin color (white/non-white; auto-declared), years of education and current alcohol consumption (yes/no) as covariates in the modeling. Odds ratios (ORs) with 95\% confidence intervals were calculated and a linear regression test was used to access the association between polymorphisms and FTND, age of initiation, and CPD (95\% CI). Alcohol consumption and gender were used as covariates for FTND and age of initiation, and age was included for CPD. The significance level for all tests was set at $\mathrm{p} \leq 0.05$.

\section{Results}

Table 1 presents the sociodemographic characteristics of the study population according to smoking status. From a total of 449 individuals, $33.6 \%$ were ever smokers, comprising current $(n=55)$ and former smokers $(n=96)$. Significant differences were detected for gender ( $p=0.006)$, age (0.003), years of education (0.002) and alcohol use (0.015). Age ranged from 18 to 87 years old. Most of the study population (74\%) auto-declared themselves as non-white, including black, medium brown, Asian, and indigenous.

Table 1 Sociodemographic characteristics of the study population.

\begin{tabular}{|c|c|c|c|c|}
\hline Variables & $\begin{array}{l}\text { Total }(n=449) \\
\text { n (\%) }\end{array}$ & $\begin{array}{l}\text { Never Smokers } \\
(\mathrm{n}=298) \\
\mathrm{n}(\%)\end{array}$ & $\begin{array}{l}\text { Ever Smokers } \\
(\mathrm{n}=151) \\
\mathrm{n}(\%)\end{array}$ & $p$ \\
\hline \multicolumn{5}{|l|}{ Gender } \\
\hline Female & $306(68.2 \%)$ & $216(72.5 \%)$ & $90(59.6 \%)$ & 0.006 \\
\hline Male & $143(31.8 \%)$ & $82(27.5 \%)$ & $61(40.4 \%)$ & 0.002 \\
\hline Age (years mean; SD) & $51.96(15.12)$ & $50.37(15.71)$ & $55.11(13.37)$ & 0.003 \\
\hline Education (years mean; SD) & $8.59(3.95)$ & $8.95(3.91)$ & $7.89(3.94)$ & 0.002 \\
\hline \multicolumn{5}{|l|}{ Skin color ${ }^{1}$} \\
\hline White & $116(26.0 \%)$ & $85(28.7 \%)$ & $31(20.7 \%)$ & 0.067 \\
\hline Non-white ${ }^{2}$ & $330(74.0 \%)$ & $211(71.3 \%)$ & $119(79.3 \%)$ & \\
\hline \multicolumn{5}{|l|}{ Alcohol consumption } \\
\hline Yes & $202(45.0 \%)$ & $122(40.9 \%)$ & $80(53.0 \%)$ & 0.015 \\
\hline No & $247(55.0 \%)$ & $176(59.1 \%)$ & $71(47.0 \%)$ & \\
\hline
\end{tabular}

The following genotype frequencies of each SNP in the population were noted: CHRNA3 rs578776-33.2\% (CC), 44.1\% (CT), 22.7\% (TT), and CHRNA5 rs16969968 - 59.9\% (GG), 32.5\% (GA), and 7.6\% (AA). The association of each polymorphism with smoking risk is displayed in Table 2 . The applied logistic regression indicated that SNP CHRNA5 rs16969868 was associated with an increased risk of smoking in women carrying the $A A$ genotype (OR: 3.09; 95\% CI: 1.09-8.76). In the recessive model $(A A v s A G+G G)$, women with the $A A$ genotype also exhibited a higher risk for smoking than the $G G+G A$ genotype (OR: 2.88; 95\% CI: 1.08-7.71). Conversely, the homozygous variant genotype TT for CHRNA3 rs578776 was significantly protective regarding the risk of smoking in the total study population, with an $O R$ of 0.48 (95\% CI: 0.26-0.89). When the recessive model (TT vs $C T+C C$ ) was applied, decreased risks were also observed in homozygous individuals for the variant TT genotype (OR: 0.9; 95\% CI: 0.35-0.99). A similar protective effect was observed in women presenting the TT CHRNA3 rs578776 genotype in comparison with the CC genotype (OR: $0.41 ; 95 \%$ CI: $0.19-0.88$ ), and when the recessive modeling was applied (OR: 0.51; 95\% CI: 0.26-0.98). 
Table 2 Association between genotypes and risk of smoking.

\begin{tabular}{|c|c|c|c|c|c|c|c|c|c|c|c|c|}
\hline & Total stud & population & $n=449$ ) & & Women ( & 06) & & & $\operatorname{Men}(n=1$ & & & \\
\hline Genotype & $\begin{array}{l}\text { Never } \\
(298)\end{array}$ & $\begin{array}{l}\text { Ever } \\
(151)\end{array}$ & $\begin{array}{l}\text { OR } \\
(95 \% \mathrm{CI})\end{array}$ & $p$ & $\begin{array}{l}\text { Never } \\
(216)\end{array}$ & $\begin{array}{l}\text { Ever } \\
(90)\end{array}$ & $\begin{array}{l}\text { OR } \\
(95 \% \mathrm{CI})\end{array}$ & $p$ & $\begin{array}{l}\text { Never } \\
(82)\end{array}$ & $\begin{array}{r}\text { Ever } \\
(61)\end{array}$ & $\begin{array}{l}\text { OR } \\
(95 \% \mathrm{CI})\end{array}$ & $p$ \\
\hline $\begin{array}{l}\text { rs16969868 } \\
\text { (CHRNA5) }\end{array}$ & n (\%) & n (\%) & & & n (\%) & n (\%) & & & n (\%) & n (\%) & & \\
\hline$G G$ & $176(59.1)$ & $93(61.6)$ & $1^{\mathrm{a}}$ & & $136(63.0)$ & $58(64.4)$ & $1^{\mathrm{a}}$ & & $40(48.8)$ & $35(57.4)$ & $1^{\mathrm{a}}$ & \\
\hline$G A$ & $103(34.6)$ & $43(28.5)$ & $\begin{array}{l}0.79 \\
(0.50-1.27)\end{array}$ & 0.344 & $69(31.9)$ & $23(25.6)$ & $\begin{array}{l}0.93 \\
(0.51- \\
1.70)\end{array}$ & 0.823 & $34(41.5)$ & $20(32.8)$ & $\begin{array}{l}0.61 \\
(0.28-1.38)\end{array}$ & 0.238 \\
\hline$A A$ & $19(6.4)$ & $15(9.9)$ & $\begin{array}{l}1.79 \\
(0.80-4.03)\end{array}$ & 0.157 & $11(5.1)$ & $9(10,0)$ & $\begin{array}{l}3.09 \\
(1,09- \\
8.76)\end{array}$ & 0.033 & $8(9.8)$ & $6(9.8)$ & $\begin{array}{l}1.08 \\
(0.28-4.16)\end{array}$ & 0.912 \\
\hline$G G+G A$ & $279(93.6)$ & $136(90.1)$ & $1^{\mathrm{a}}$ & & $205(94.9)$ & $81(90.0)$ & $1^{\mathrm{a}}$ & & $74(90.2)$ & $55(90.2)$ & $1^{\mathrm{a}}$ & \\
\hline$A A$ & $19(6.4)$ & $15(9.9)$ & $\begin{array}{l}1.92 \\
(0.90-4.14)\end{array}$ & 0.093 & $11(5.1)$ & $9(10.0)$ & $\begin{array}{l}2.88 \\
(1.08- \\
7.71)\end{array}$ & 0.035 & $8(9.8)$ & $6(9.8)$ & $\begin{array}{l}1.33 \\
(0.37-4,76)\end{array}$ & 0.661 \\
\hline $\begin{array}{l}\text { rs578776 } \\
\text { (CHRNA3) }\end{array}$ & N (\%) & N (\%) & & & N (\%) & N (\%) & & & N (\%) & N (\%) & & \\
\hline$C C$ & $93(31.2)$ & $56(37.1)$ & $1^{\mathrm{a}}$ & & $62(28.7)$ & $33(36.7)$ & $1^{\mathrm{a}}$ & & $31(37.8)$ & $23(37.7)$ & $1^{\mathrm{a}}$ & \\
\hline$C T$ & $130(43.6)$ & $68(45.0)$ & $\begin{array}{l}0.80 \\
(0.50-1.26)\end{array}$ & 0.344 & $98(45.4)$ & $42(46.7)$ & $\begin{array}{l}0.73 \\
(0.41- \\
1.30)\end{array}$ & 0.290 & $32(39.0)$ & $26(42.6)$ & $\begin{array}{l}1.00 \\
(0.44-2.30)\end{array}$ & 0.998 \\
\hline$T T$ & $75(25.2)$ & $27(17.9)$ & $\begin{array}{l}0.48 \\
(0.26-0.89)\end{array}$ & 0.019 & $56(25.9)$ & $15(16.7)$ & $\begin{array}{l}0.41 \\
(0.19- \\
0.88)\end{array}$ & 0.022 & $19(23.2)$ & $12(19.7)$ & $\begin{array}{l}0.59 \\
(0.20-1.71)\end{array}$ & 0.329 \\
\hline$C C+C T$ & $223(74.8)$ & $124(82.1)$ & $1^{\mathrm{a}}$ & & $160(74,1)$ & $75(83.3)$ & $1^{\mathrm{a}}$ & & $63(76.8)$ & $49(80.3)$ & $1^{\mathrm{a}}$ & \\
\hline$T T$ & $75(25.2)$ & $27(17.9)$ & $\begin{array}{l}0.9 \\
(0.35-0.99)\end{array}$ & 0.045 & $56(25.9)$ & $15(16.7)$ & $\begin{array}{l}0.51 \\
(0.26- \\
0.98)\end{array}$ & 0.043 & $19(23.2)$ & $12(19.7)$ & $\begin{array}{l}0.69 \\
(0.28-1.72)\end{array}$ & 0.426 \\
\hline
\end{tabular}

$\mathrm{OR}$ = odds ratio adjusted by age, gender, alcohol consumption, years of education and skin color; $\mathrm{CI}$ = Confidence Interval; a Reference group; p-value obtained by a logistic regression. 
Table 3 Polymorphism association with age of smoking initiation.

\begin{tabular}{|c|c|c|c|c|c|c|c|c|c|c|c|c|}
\hline \multirow[b]{2}{*}{$\begin{array}{l}\text { rs16969868 } \\
\text { (CHRNA5) }\end{array}$} & \multicolumn{4}{|c|}{ Total study population $(n=146)$} & \multicolumn{4}{|c|}{ Women $(n=88)$} & \multicolumn{4}{|c|}{ Men $(n=58)$} \\
\hline & $\mathbf{n}$ & Mean & $95 \% \mathrm{CI}$ & $p$ & $\mathbf{n}$ & Mean & $95 \% \mathrm{CI}$ & $p$ & $\mathbf{n}$ & Mean & $95 \%$ CI & $p$ \\
\hline$G G$ & 89 & 16.49 & $15.46-17.53$ & $1^{\mathrm{a}}$ & 56 & 17.00 & $15.43-18.53$ & $1^{\mathrm{a}}$ & 33 & 15.64 & $14.57-16.70$ & $1^{\mathrm{a}}$ \\
\hline$G A$ & 43 & 15.33 & $14.15-16.50$ & 0.463 & 23 & 14.52 & $12.89-16.15$ & 0.177 & 20 & 16.25 & 14.51-17.99 & 0.233 \\
\hline$A A$ & 14 & 14.57 & $12.31-16.83$ & 0.297 & 9 & 15.44 & $12.34-18.55$ & 0.657 & 5 & 13.00 & $8.61-17.39$ & 0.269 \\
\hline$G G+G A$ & 132 & 16.11 & $15.32-16.91$ & $1^{\mathrm{a}}$ & 79 & 16.28 & $15.08-17.47$ & $1^{\mathrm{a}}$ & 53 & 15.87 & $14.96-16.77$ & $1^{\mathrm{a}}$ \\
\hline$A A$ & 14 & 14.57 & $12.31-16.83$ & 0.357 & 9 & 15.44 & $12.34-18.55$ & 0.854 & 5 & 13.00 & $8.61-17.39$ & 0.308 \\
\hline $\begin{array}{l}\text { rs578776 } \\
\text { (CHRNA3) }\end{array}$ & $\mathbf{n}$ & Mean & $95 \% \mathrm{CI}$ & $p$ & $\mathbf{n}$ & Mean & $95 \% \mathrm{CI}$ & $p$ & $\mathbf{n}$ & Mean & $95 \% \mathrm{CI}$ & $p$ \\
\hline$C C$ & 54 & 15.17 & $14.03-16.30$ & $1^{\mathrm{a}}$ & 32 & 15.56 & $13.84-17.29$ & $1^{\mathrm{a}}$ & 22 & 14.59 & $13.25-15.94$ & $1^{\mathrm{a}}$ \\
\hline$C T$ & 68 & 16.03 & $14.95-17.11$ & 0.340 & 42 & 15.83 & $14.31-17.36$ & 0.790 & 26 & 16.35 & $14.85-17.84$ & 0.397 \\
\hline$T T$ & 24 & 17.58 & $15.30-19.87$ & 0.048 & 14 & 18.71 & $14.92-22.51$ & 0.040 & 10 & 16.00 & $14.00-18.00$ & 0.559 \\
\hline$C C+C T$ & 122 & 15.65 & $14.87-16.42$ & $1^{\mathrm{a}}$ & 74 & 15.72 & $14.60-16.83$ & $1^{\mathrm{a}}$ & 48 & 15.54 & $14.53-16.56$ & $1^{\mathrm{a}}$ \\
\hline$T T$ & 24 & 17.58 & $15.30-19.87$ & 0.067 & 14 & 18.71 & $14.92-22.51$ & 0.050 & 10 & 16.00 & $14.00-18.00$ & 0.303 \\
\hline
\end{tabular}


Table 3 presents the linear regression analysis for age of smoking initiation according to the CHRNA3 rs578776 and CHRNA5 rs16969968 polymorphisms in the overall study population and in women subjects. The TT genotype for CHRNA3 rs578776 was associated with later initiation in comparison to the $C C$ genotype (mean $=18.71 ; 95 \% \mathrm{CI}$ : 14.92 $22.51 ; p=0.04$ ), and overall population (mean=17.58; $95 \% \mathrm{CI}: 0.19-0.88 ; p=0.05$ ). Individuals homozygous for the $T$ allele began smoking about two and three years later than allele $C$ homozygous subjects in the overall study population and in women subjects, respectively (Figure 1). No significant difference was noted for men. Regarding FTND and CPD, the linear regression analysis results indicated no association with CHRNA3 polymorphisms. For the CHRNA5 (rs16969968) SNP, a lower mean age of initiation for the $A A$ genotype compared to $G G$ and $A G$ genotypes was observed, albeit non-statistically significant, as displayed in Table 3. Likewise, FTND score and CPD were not associated to SNPs (data not shown).

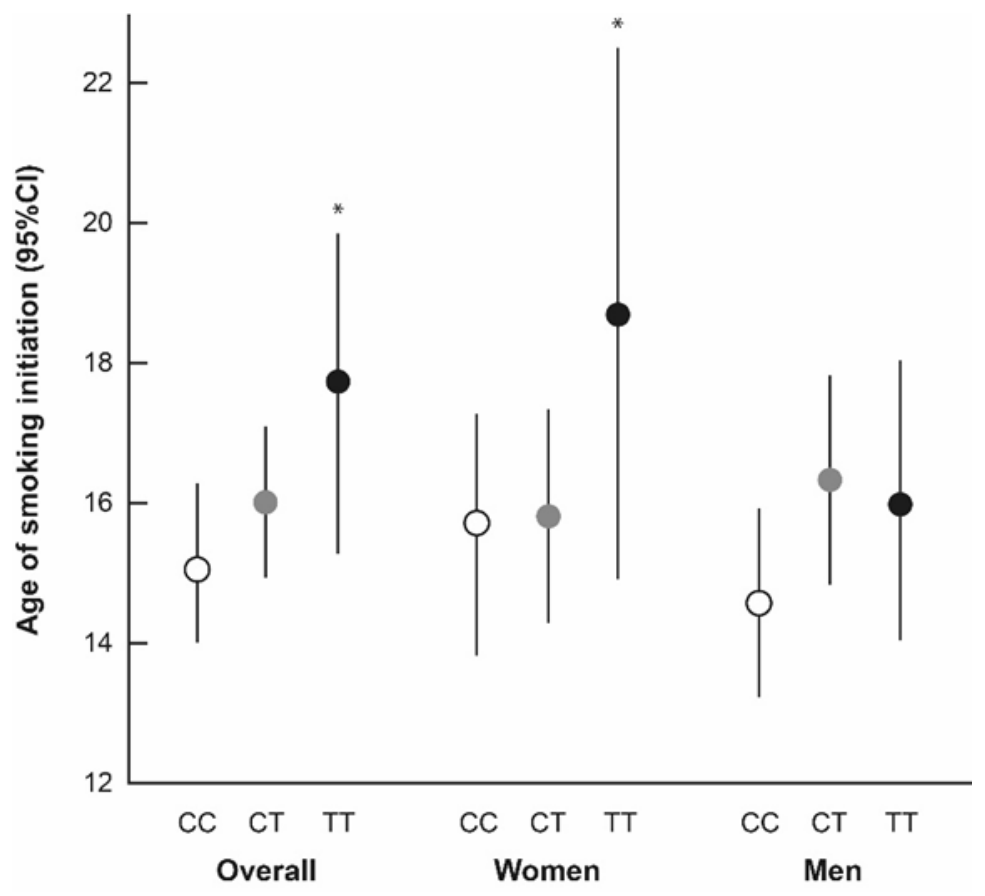

Figure 1 Age of smoking initiation among genotypes for CHRNA3 rs578776.

Mean age of smoking initiation is presented at a 95\% confidence interval (CI), using CC as reference in the regression analysis. ${ }^{*} p$ value was $\leq 0.05$.

\section{Discussion}

Possible associations between CHRNA5 rs16969968 and CHRNA3 rs578776 SNPs and the risk of smoking and smoking behavior in a Brazilian population were evaluated, since these SNPs have been linked to interindividual variability concerning nicotine responses. CHRNA5 rs16969968 and CHRNA3 rs578776, have been investigated as candidates of genetic factors for risk of smoking susceptibility and protection, respectively.

The distribution of variant SNP alleles varies according to population ethnicity. For CHRNA5 rs16969968, the frequencies of allele A are higher in Europeans/Caucasians, at approximately 42\%, and lower in Asians and Africans descendants, ranging from 0 to $3 \%(12,27,28,29)$. The inverse is noted for CHRNA3 rs578776. The presence of allele $T$ is lower in Caucasians (24\%), and higher in African descendants (80\%) and Asians (65\%) [29]. The Brazilian population is known to be highly mixed, due to the presence of diverse ethnicities in its establishment [30]. In the present study, most of the participants reported themselves as black, medium brown, indigenous or Asians (74\%). Herein, variant allele frequencies were $24 \%$ and $45 \%$ for CHRNA5 rs16969968 and CHRNA3 rs578776, respectively. This distribution appears to be intermediary compared to other populations, and similar to previous studies performed on Brazilian populations $[22,23]$. 
The CHRNA5 rs16969968 and CHRNA3 rs578776 SNPs were shown to influence smoking risks, with their recessive genotypes indicating a higher risk of smoking for CHRNA5 rs16969968, and protective effect for CHRNA3 rs578776. An association between the TT genotype of CHRNA3 rs578776 and later initiation age in the overall population was also verified, particularly in women, but not in men. These results are in accordance with previous studies carried out in Caucasian populations [14,28,31,32,33]. No investigations regarding increased risk or protection against smoking in Brazilian population have been conducted for CHRNA5 rs16969968 and CHRNA3 rs578776. In addition, few molecular mechanism propositions for these effects are available in literature. For the CHRNA5 rs16969968 variant allele $A$, a possible explanation is that an amino acid replacement in the receptor caused by the $G>A$ variation in the gene appears to decrease receptor responses to nicotine, leading to an increased need for consumption [28]. With regard to CHRNA3 SNP, however, no plausible explanation for its protective effect has been postulated.

In the present study, gender was proven to be a relevant factor, which should be taken into account in other investigations on genetic variability associated to smoking. The CHRNA3 rs578776 variant was associated to protection against smoking in the overall population and in women, but not in men. The same was noted for the CHRNA5 rs16969968 variant, only associated with increased risk of smoking in women. Some authors have suggested that women tend to evolve from experimentation to addiction more quickly and have greater difficulty in quitting smoking $[34,35]$. Additionally, they are more susceptible due to hormonal differences [36]. Several studies providing evidence of gender influence on the genetic-smoking relationship are available [9,11,35]. Interestingly, as association between the assessed SNPs and smoking was only observed for the homozygous variant genotypes, in accordance to other reports for European populations [28,32,37].

FTND, CPD, and initiation were evaluated as smoking behavior characteristics associated to the CHRNA5 rs16969968 and CHRNA3 rs578776 polymorphisms among ever smokers. A significant association was observed for initiation, but not with FTND and CPD, probably due to the reduced sample size of ever smokers. Subjects homozygote for the $C$ variant of $C H R N A 3$ rs578776 began smoking 2 years earlier than those presenting the TT genotype. This indicates that the CHRNA3 rs578776 variant has a protective effect on age of smoking initiation in the overall population, which is stronger in women. Even with no statistically significant difference, subjects with CHRNA5 rs16969968 variant AA genotype started smoking about 2 years earlier than those presenting other genotypes. Although few studies focusing on the interference of genetic variations in smoking initiation of smoking are available, the findings reported herein were in accordance with other assessments [12-14,37,38], who reported that people who began smoking earlier exhibited a greater risk of smoking dependence. Weiss et al. only observed an association between CHRNA5 rs16969868 AA and CHRNA3 rs578776 TT, established risk and protection genotypes, respectively, and smoking dependence in adults who began smoking up to 16 years old [14].

The major limitation of this study comprises the inability to assess a possible combined effect of the risk CHRNA5 rs16969968 SNP and protective CHRNA3 rs578776 SNP on smoking, due to an insufficient sample size. This could indicate whether the homozygous variant genotype TT CHRNA3 rs578776 may minimize increased smoking risks associated to the CHRNA5 rs16969968 variant, and may have been the reason for the lack of association between the evaluated SNPs and FTDN and CPD.

\section{Conclusion}

In conclusion, the CHRNA5 (rs16969968) variant was only associated with a higher risk of smoking in women, while the CHRNA3 (rs578776) variant was associated with a protective effect regarding risk of smoking and with age of smoking initiation in both the overall study population and in women. For both SNPs, the association was only statistically significant in subjects with variant homozygote genotypes, i.e., the presence of one copy of the allele variant did not affect smoking. Gender influenced the effects of the CHRNA5 rs16969968 and CHRNA3 rs578776 polymorphisms on smoking. This study contributes to elucidate the influence of the CHRNA5 rs16969968 and CHRNA3 rs578776 variants on smoking, especially in the Brazilian population, and may aid in advancing smoking cessation treatments.

\section{Compliance with ethical standards}

\section{Acknowledgments}

This study was supported by Sergio Arouca National School of Public Health/Oswaldo Cruz Foundation (ENSP/FIOCRUZ) (ENSP-018-FIO-17) and the Research Support Foundation of the State of Rio de Janeiro (FAPERJ) (E26/200.618/2018), Brazil. 


\section{Disclosure of conflict of interest}

There is no conflict of interest in publishing the present data of the study.

\section{Statement of informed consent}

Informed consent was obtained from all individual participants included in the study.

\section{References}

[1] World Health Organization. (WHO). (2019).Who report on the global tobacco epidemic 2019: Offer Help to Quit Tobacco Use. World Health Organization, Geneva, 18-19.

[2] National Center for Chronic Disease Prevention and Health Promotion (US) Office on Smoking and Health (NCCDPHP). (2014). The Health Consequences of Smoking-50 Years of Progress: A Report of the Surgeon General. Centers for Disease Control and Prevention, Atlanta, 1-7.

[3] Benowitz NL. (2010). Nicotine addiction. The New England Journal of Medicine, 362(24), 2295-2303.

[4] Nestler EJ. (2005). Is there a common molecular pathway for addiction? Nature Neuroscience, 8(11), 1445-1449.

[5] Improgo MRD, Scofield MD, Tapper AR and Gardner PD. (2010). From smoking to lung cancer: the CHRNA5/A3/B4 connection. Oncogene, 29(35), 4874-4884.

[6] Schmidt HD, Rupprecht LE and Addy NA. (2018). Neurobiological and Neurophysiological Mechanisms Underlying Nicotine Seeking and Smoking Relapse. Molecular Neuropsychiatry, 4(4), 169-189.

[7] LI MD. (2018). Involvement of Variants in Gene Clusters CHRNA5/A3/B4 on Chromosome 15 to Smoking Behaviors and Lung Cancer. In: Tobacco Smoking Addiction: Epidemiology, Genetics, Mechanisms, and Treatment. Springer, Singapore, 47-69.

[8] Yang J and Li MD. (2016). Converging findings from linkage and association analyses on susceptibility genes for smoking and other addictions. Molecular Psychiatry, 21(8), 992-1008.

[9] Lips EH; Gaborieau V, McKay JD, Chabrier A, Hung RJ, Boffetta P, Hashibe M, Zaridze D, Szeszenia-Dabrowska N, Lissowska J, Rudnai P, Fabianova E, Mates D, Bencko V, Foretova L, Janout V, Field JK, Liloglou T, Xinarianos G, McLaughlin J, Liu G, Skorpen F, Elvestad MB, Hveem K, Vatten L, Study E, Benhamou S, Lagiou P, Holcátová I, Merletti F, Kjaerheim K, Agudo A, Castellsagué X, Macfarlane TV, Barzan L, Canova C, Lowry R, Conway DI, Znaor A, Healy C, Curado MP, Koifman S, Eluf-Neto J, Matos E, Menezes A, Fernandez L, Metspalu A, Heath S, Lathrop M and Brennan P. (2010). Association between a 15q25 gene variant, smoking quantity and tobacco-related cancers among 17000 individuals. International Journal of Epidemiology, 39(2), 563-577.

[10] Sieminska A, Jassem E and Kita-Milczarska K. (2015). Nicotine dependence in an isolated population of Kashubians from North Poland: a population survey. BMC Public Health, 15(1), 80.

[11] Conlon MS and Bewick MA. (2011). Single Nucleotide Polymorphisms in CHRNA5 rs16969968, CHRNA3 rs578776, and LOC123688 rs8034191 Are Associated with Heaviness of Smoking in Women in Northeastern Ontario, Canada. Nicotine and Tobacco Research, 13(11), 1076-1083.

[12] Zhu AZX, Renner CC, Hatsukami DK, Benowitz NL and Tyndale RF. (2013). CHRNA5-A3-B4 genetic variants alter nicotine intake and interact with tobacco use to influence body weight in Alaska Native tobacco users: CHRNA5A3-B4 in Alaska Native people. Addiction, 108(10), 1818-1828.

[13] Buczkowski K, Sieminska A, Linkowska K, Czachowski S, Przybylski G, Jassem E and Grzybowski T. (2015). Association between Genetic Variants on Chromosome 15q25 Locus and Several Nicotine Dependence Traits in Polish Population: A Case-Control Study. BioMed Research International, 350348.

[14] Weiss RB, Baker TB, Cannon DS, von Niederhausern A, Dunn DM, Matsunami N, Singh NA, Baird L, Coon H, McMahon WM, Piper ME, Fiore MC, Scholand, Connett JE, Kanner RE, Gahring LC, Rogers SW, Hoidal JR and Leppert MF. (2008). A Candidate Gene Approach Identifies the CHRNA5-A3-B4 Region as a Risk Factor for AgeDependent Nicotine Addiction. PLoS Genetics, 4(7), e1000125.

[15] Erlich PM, Hoffman SN, Rukstalis M, Han JJ, Chu X, Linda Kao WH, Gerhard GS, Stewart WF and Boscarino JA. (2010). Nicotinic acetylcholine receptor genes on chromosome 15q25.1 are associated with nicotine and opioid dependence severity. Human Gene, 128(50, 491-499. 
[16] Belsky DW, Moffitt TE, Baker TB, Biddle AK, Evans JP, Harrington H, houts R, Meier M, Sugden K, Williams B, Poulton R and Caspi A. (2013). Polygenic Risk and the Developmental Progression to Heavy, Persistent Smoking and Nicotine Dependence: Evidence From a 4-Decade Longitudinal Study. JAMA Psychiatry, 70(5), 534-542.

[17] Chuang Y-H, Paul KC, Sinsheimer JS, Bronstein JM, Bordelon YM and Ritz B. (2019). Genetic variants in nicotinic receptors and smoking cessation in Parkinson's disease. Parkinsonism \& Related Disorders, 62, 57-61.

[18] Wang Q, Li S, Pan L, Li H, Yang X, Jiang F, Zhang N and Han M and Jia C. (2016). Association between variants in nicotinic acetylcholine receptor genes and smoking cessation in a Chinese rural population: Association of Genes with Smoking Cessation. The American Journal on Addictions, 25(4), 297-300.

[19] Caporaso N, Gu F, Chatterjee N, Sheng-Chih J, Yu K, Yeager M, Yeager M, Jacobs K, Landi MT, Ziegler RG, Chanok S, Kraft P, Bergen AW, Chen C, Wheeler W, Hunter DJ and Hankinson SE. (2009). Genome-Wide and Candidate Gene Association Study of Cigarette Smoking Behaviors. PLoS ONE, 4(2), e4653.

[20] Stevens VL, Bierut LJ, Talbot JT, Wang JC, Sun J, Hinrichs AL, Thun MJ, Goate A and Calle EE. (2008). Nicotinic Receptor Gene Variants Influence Susceptibility to Heavy Smoking. Cancer Epidemiology, Biomarkers \& Prevention, 17(12), 3517-3525.

[21] Pérez-Rubio G, Córdoba-Lanús E, Cupertino P, Cartujano-Barrera F, Campos MA and Falfán-Valencia R. (2019). Role of Genetic Susceptibility in Nicotine Addiction and Chronic Obstructive Pulmonary Disease. Revista de Investigação Clinica, 71(1), 36-54.

[22] Tomaz PRX, Santos JR, Scholz J, Abe TO, Gaya PV, Negrão AB, Kreger JE, Pereira AC and Santos PCJL. (2018). Cholinergic receptor nicotinic alpha 5 subunit polymorphisms are associated with smoking cessation success in women. Molecular Genetics \& Genomic Medicine, 19(1), 55.

[23] Silva MR, Gattás GJF, Antonio J, Firigato I, Curioni OA and Gonçalves F de T. Polymorphisms of CHRNA3 and CHRNA5: Head and neck cancer and cigarette consumption intensity in a Brazilian population. Molecular Genetics \& Genomic Medicine, 7(12), e998.

[24] Brazil. Ministry of Health, Secretariat of Health Surveillance, Department of Health Analysis and Surveillance of Noncommunicable Diseases. (2020). Vigitel Brasil 2019: vigilância de fatores e risco e proteção para doenças crônicas por inquérito telefônico. Ministério da Saúde, Brasília, 27-36.

[25] Pinto M, Bardac A, Palacios A, Bin A, Alcaraz A, Rodríguez B and Augustovski F e Pichon-Riviere A. (2017). Carga de doença atribuível ao uso do tabaco no Brasil e potencial impacto do aumento de preços por meio de impostos. INCA - Instituto Nacional de Câncer. Documento técnico IECS N²1. Instituto de Efectividad Clínica y Sanitaria, Buenos Aires, 19-22.

[26] Sales MPU, Araújo AJ de, Chatkin JM, Godoy I, Pereira LFF, Castellano MVC de O, Tanni SE, Almeida AA, Chatkin G, Silva LCC, Gonçalves CMC, Botelho C, Santos UP, Viegas CA de A, Sestelon MR, Meireles RHA, Correa PCRP, Oliveira MEM, Reichert J, Lima MS and Silva CAR. (2019). Update on the approach to smoking in patients with respiratory diseases. Jornal Brasileiro de Pneumologia, 45(3), e20180314.

[27] Robinson JD, Versace F, Lam CY, Minnix JA, Engelmann JM, Cui Y, Karam-Hage M, Shete SS, Tomlinson GE, Chen TTL, David WW, Charles EG and Cincipirini PM. (2013). The CHRNA3 rs578776 Variant is Associated with an Intrinsic Reward Sensitivity Deficit in Smokers. Frontiers in Psychiatry, 4, 114.

[28] Bierut LJ, Stitzel JA, Wang JC, Hinrichs AL, Grucza RA, Xuei X, Saccone N, Saccone SF, Bertelsen S, Fox L, Horton WL, Breslau N, Budde J, Cloninger CR, Dick DM, Foround T, Hatsukami D, Hesselbrock V. Johnson EO, Karmer J, Kuperman S, Madden PAF, Mayo K, Nurnberger J, Pomerleau O, Porjesz B, Reyes O, Schuckit M, Swan G, Tischfield JA, Edenberg HJ, Rice JP and Goate AM. (2008). Variants in Nicotinic Receptors and Risk for Nicotine Dependence. American Journal of Psychiatry, 165(9), 1163-1171.

[29] Bierut LJ. (2009). Nicotine dependence and genetic variation in the nicotinic receptors. Drug and Alcohol Dependence, 104 (Suppl 1), S64-69.

[30] Lins TC, Vieira RG, Abreu BS, Grattapaglia D and Pereira RW. (2009). Genetic composition of Brazilian population samples based on a set of twenty-eight ancestry informative SNPs. American Journal of Human Biology, 22(2), 187-192.

[31] Saccone NL, Wang JC, Breslau N, Johnson EO, Hatsukami D, Saccone SF, Grucza RA, Sun L, Duan W, Budde J, Culverhouse RC, Fox L, Hinrichs AL, Steinbach JH, Wu M, Rice JP, Goate AM and Bierut LJ. (2009). The CHRNA5CHRNA3-CHRNB4 Nicotinic Receptor Subunit Gene Cluster Affects Risk for Nicotine Dependence in AfricanAmericans and in European-Americans. Cancer Research, 69(17), 6848-6856. 
[32] Saccone SF, Hinrichs AL, Saccone NL, Chase GA, Konvicka K, Madden PAF, Breslau N, Johnson EO, Hatsukami D, Pomerleau O, Swan GE, Swan GE, Goate AM, Rutter J, Bertelsen S, Fox L, Fugman D, Martin NG, Montgomery GW, Wang JC, Ballinger DG, Rice JP and Bierut LJ. (2007). Cholinergic nicotinic receptor genes implicated in a nicotine dependence association study targeting 348 candidate genes with 3713 SNPs. Human Molecular Genetics, 16(1), 36-49.

[33] Hubacek JA, Pankova A, Stepankova L, Zvolska K, Adamkova V, Lanska V and Kralikova E. (2017). SNPs within CHRNA5-A3-B4 and CYP2A6/B6 are associated with smoking dependence but not with tobacco dependence treatment outcomes in the Czech population. Gene, 606, 35-38.

[34] Smith PH, Bessette AJ, Weinberger AH, Sheffer CE and McKee SA. (2016). Sex/gender differences in smoking cessation: A review. Preventive Medicine, 92, 135-140.

[35] Petersen N and London ED. (2018). Addiction and dopamine: sex differences and insights from studies of smoking. Current Opinion in Behavioral Sciences, 23, 150-159.

[36] Park SJ, Yi B, Lee HS, Oh WY, Na HK, Lee M and Yang M. (2016). To quit or not: Vulnerability of women to smoking tobacco. Journal of Environmental Science and Health, Part C, 34(1), 33-56.

[37] Rodriguez S, Cook DG, Gaunt TR, Nightingale CM, Whincup PH and Day IN. (2011). Combined analysis of CHRNA5, CHRNA3 and CYP2A6 in relation to adolescent smoking behaviour. Journal of Psychopharmacology, 25(7), 915923.

[38] Grucza RA, Wang JC, Stitzel JA, Hinrichs AL, Saccone SF, Saccone NL, Bucholz K, Cloninger CR, Neuman RJ, Budde JP, Fox L, Bertelsen S, Kramer J, Hesselbrock V, Tischfielld J, Nurberger JI, Almasy L, Porjesz B, Kuperman S, Schuckit MA, Edenberg HJ, Rice JP, Goat AM and Bierut LJ. (2008). A Risk Allele for Nicotine Dependence in CHRNA5 Is a Protective Allele for Cocaine Dependence. Biological Psychiatry, 64(11), 922-929. 